\title{
THE SIMULTANEOUS DETERMINATION OF RED CELL MASS AND PLASMA VOLUME IN MAN WITH RADIOACTIVE SODIUM CHROMATE AND CHROMIC CHLORIDE ${ }^{1}$
}

\author{
By SEYMOUR J. GRAY AND HEDDY FRANK \\ (From the Biophysical Laboratory and the Department of Medicine, Harvard Medical School, \\ and the Medical Clinic, Peter Bent Brigham Hospital, Boston, Mass.)
}

(Submitted for publication March 16, 1953; accepted June 22, 1953)

The use of radioactive chromium in the determination of the circulating red cell mass $(1,2)$ and the plasma volume $(3,4)$ in man has been reported previously. Anionic hexavalent chromium $\left(\mathrm{Na}_{2} \mathrm{Cr}^{51} \mathrm{O}_{4}\right)$ is readily taken up by erythrocytes in vitro and retained by them after reinjection without appreciable loss to the plasma for approximately 24 hours. Cationic trivalent chromium in the form of chromic chloride readily tags plasma proteins in vivo and in vitro. At least 98 per cent of the radioactive chromic chloride is bound to the plasma proteins with minimal loss of the isotope to the red cells.

Because of the selective affinity of erythrocytes for hexavalent anionic $\mathrm{Cr}^{51}$ and of the plasma proteins for trivalent cationic $\mathrm{Cr}^{51}$, it seemed possible to use these two forms of the isotope for the simultaneous determination of red cell mass and plasma volume in human subjects.

Simultaneous measurements of red cell mass and plasma volume were made on ten normal adult subjects with radioactive chromium. The accuracy of the combined technique was confirmed by making determinations immediately before and after the transfusion of a measured volume of blood.

\section{METHODS}

\section{Tagging, injecting, and sampling procedure}

The combined method consists of tagging the subject's red cells in vitro with radioactive sodium chromate and reinjecting a saline suspension of the tagged cells. After the tagged cells have mixed in the circulation, the radioactivity of the subject's erythrocytes is determined and the circulating red cell mass may be calculated by the radioisotope dilution principle $(1,2)$. When the ten-minute sample of blood is withdrawn, a solution of radioactive chromic chloride is injected intravenously. The dilution curve of the isotope in the plasma is obtained by deter-

1 This work was supported in part by the United States Atomic Energy Commission and the United States Public Health Service. mining the radioactivity of four samples of plasma drawn at five-minute intervals after the injection of the chromic chloride, and the plasma volume may then be calculated by the radioisotope dilution principle (4).

Approximately $50 \mathrm{ml}$. of blood are drawn from the subject into a sterile heparinized syringe. This is poured into a sterile flask containing approximately. $25 \mathrm{ml}$. of saline and 200 microcuries of $\mathrm{Cr}^{61}$ as $\mathrm{Na}_{2} \mathrm{Cr}^{61} \mathrm{O}_{4}{ }^{2}$ The blood is allowed to stand at room temperature for one hour in contact with the isotope, with occasional shaking. At the end of this time the red cells have acquired about 50 per cent of the counts, or 100 microcuries $\mathrm{Cr}^{85}$.

The contents of the flask are then filtered through sterile gauze and centrifuged in the cold. The supernatant saline and plasma are removed and the red cells are washed three times with cold sterile saline and finally resuspended in approximately $25 \mathrm{ml}$. of cold sterile saline.

An aliquot of this red cell suspension is saved for counting and the remainder, approximately $40 \mathrm{ml}$., is placed in a sterile calibrated syringe for reinjection. To reduce the chances of contamination and bacterial growth, the tagged red cells are reinjected the same day, and no febrile reactions have been encountered. Penicillin may be added to the injecting solution, as an additional precautionary measure.

Ten ml. of blood are drawn into an heparinized syringe from the antecubital vein, as the control sample for the plasma volume determination. Syringes are changed and the tagged red cell suspension is injected through the same needle. After ten minutes, another $10 \mathrm{ml}$. sample of blood is obtained and again syringes are changed for the injection of the chromic chloride solution $(25 \mathrm{ml}$. of saline containing approximately 100 microcuries of $\mathrm{Cr}^{\text {si }}$ ). After the injection of chromic chloride, four samples of blood are taken at five-minute intervals from the arm opposite to that used for injection.

\section{Preparation of samples for counting}

The radioactivity of the red cells and plasma can be determined in liquid samples on a liquid sample scintillation counter (W. S. McDonald Co., Inc., counter type 155 , detector head type 152-H5) or on a well type gamma ray counter (Texas Co. type 18-20 TR). The red cells and plasma may also be dried, and counting can then be

${ }^{2} \mathrm{Na}_{2} \mathrm{Cr}^{51} \mathrm{O}_{4}$ may be prepared from $\mathrm{Cr}^{51} \mathrm{O}_{3}$ by the method previously described (3) or may be obtained from $\mathrm{Ab}$ bott Laboratories. 
TABLE I

Counting rates of red cell and plasma samples on different counters

\begin{tabular}{|c|c|c|c|c|c|c|}
\hline \multirow[b]{2}{*}{ Type of counter } & \multirow[b]{2}{*}{$\begin{array}{c}\text { Per cent } \\
\text { efficiency }\end{array}$} & \multirow[b]{2}{*}{$\begin{array}{l}\text { Back- } \\
\text { ground }\end{array}$} & \multicolumn{2}{|c|}{ Red cells } & \multicolumn{2}{|c|}{ Plasma } \\
\hline & & & $\begin{array}{l}\text { Type of } \\
\text { sample }\end{array}$ & $\begin{array}{l}\text { Corrected } \\
\text { counts } \\
\text { per minute } \\
\text { per sample }\end{array}$ & $\begin{array}{l}\text { Type of } \\
\text { sample }\end{array}$ & $\begin{array}{c}\text { Corrected } \\
\text { counts } \\
\text { per minute } \\
\text { per sample }\end{array}$ \\
\hline Scintillation & 2.96 & 450 & $\begin{array}{c}\text { Liquid } \\
2 \mathrm{ml} 1: 1 \\
\text { red cell } \\
\text { hemolysate }\end{array}$ & 2800 & $\begin{array}{c}\text { Liquid } \\
2 \mathrm{ml} . \\
\text { plasma }\end{array}$ & 4430 \\
\hline Texaco Well & .3 & 390 & $\begin{array}{c}6 \mathrm{ml} .1: 1 \\
\text { red cell } \\
\text { hemolysate }\end{array}$ & 760 & $\begin{array}{c}5 \mathrm{ml} . \\
\text { plasma }\end{array}$ & 1000 \\
\hline $\begin{array}{l}\text { Geiger Muller } \\
\text { Amperex Tube }\end{array}$ & .54 & 10 & $\begin{array}{c}\text { Dried } \\
1 \mathrm{ml} .1: 25 \\
\text { red cell } \\
\text { hemolysate }\end{array}$ & 20 & $\begin{array}{c}\text { Dried } \\
1 \mathrm{ml} . \\
\text { plasma }\end{array}$ & 230 \\
\hline $\begin{array}{l}\text { Geiger Muller } \\
\text { Tracer Lab Tube }\end{array}$ & .78 & 18 & $\begin{array}{c}1 \mathrm{ml} \text { 1:25 } \\
\text { red cell } \\
\text { hemolysate }\end{array}$ & 30 & $\begin{array}{c}1 \mathrm{ml} . \\
\text { plasma }\end{array}$ & 335 \\
\hline Proportional flow & 23.6 & 20 & $\begin{array}{c}1 \mathrm{ml} .1: 25 \\
\text { red cell } \\
\text { hemolysate }\end{array}$ & 200 & $\begin{array}{l}1 \mathrm{ml} . \\
\text { plasma }\end{array}$ & 3350 \\
\hline
\end{tabular}

done on an end-window Geiger counter (North American Phillips, tube type 62017-Amperex or Tracerlab Inc., tube TCG 3) or on a windowless flow type proportional counter (modification of the counter described by C. V. Robinson) (5).

\section{A. Liquid sample counting method:}

Four ml. of whole blood from the sample obtained 10 minutes after the injection of the tagged erythrocytes are placed in a $4 \mathrm{ml}$. hematocrit tube. This is centrifuged at approximately $2700 \mathrm{rpm}$. at a radius of $14 \mathrm{~cm}$. for 60 minutes in the cold room. The supernatant plasma is removed and the remaining packed red cells are hemolyzed with exactly their own volume of distilled water. Two $\mathrm{ml}$. aliquots of this hemolysate are pipetted into small rimless culture tubes for counting in the scintillation counter. The contents of each tube correspond to $1 \mathrm{ml}$. packed erythrocytes (Table I).

For the determination of the counts contained in the injected red cells, an aliquot of the tagged red cell suspension in saline is also centrifuged in a $4 \mathrm{ml}$. hematocrit tube for one hour at $2700 \mathrm{rpm}$. After removal of the supernatant saline, the red cells are hemolyzed in the same manner as the other sample, but the hemolysate is then further diluted with 25 volumes of water in order to bring its counting range within that of the other samples. Hematocrit corrections are not necessary since the amount of plasma or saline trapped is constant and both plasma and saline are free of counts. Washing of red cells to remove plasma, particularly in samples obtained after the injection of radioactive chromic chloride, does not seem to be necessary.
For the plasma volume determination, the blood sample obtained ten minutes after injection of the tagged red cells and just before the injection of the chromic chloride solution serves as the control sample. This and the four samples obtained after the injection of chromic chloride are centrifuged to separate the plasma. Exactly $2 \mathrm{ml}$. aliquots of these five plasma samples are pipetted into small rimless culture tubes for counting. A saved aliquot of the injected chromic chloride solution is diluted 1:50 and $1 \mathrm{ml}$. of this is also counted in a small rimless culture tube.

All of these specimens are then ready for immediate counting in the scintillation counter. For a counter with lower efficiency, such as a well type gamma ray counter, larger aliquots of red cell hemolysates and plasma ( 5 to 7 ml.) should be used in order to obtain reasonable counting rates (Table $\mathrm{I}$ ). No correction for absorption is necessary for either of these gamma ray counters.

\section{B. Dried sample counting method:}

The red blood cells can be prepared for counting as dried ground cells or as dried 1:25 red cell hemolysates (2). The hemolysate method is simpler and more rapid than the ground red cell method and has been used exclusively in this study. In preparing the hemolysates, $4 \mathrm{ml}$. hematocrit tubes are filled approximately one-third with whole blood and centrifuged at $2700 \mathrm{rpm}$. for one hour. After removal of the plasma, the packed red cells are diluted to precisely five times their initial volume with distilled water as read from the calibration on the hematocrit tubes. The tubes are covered with Parafilm and inverted at least ten times to ensure complete hemolysis. 
Two-tenths $\mathrm{ml}$. aliquots of the hemolysates are pipetted into aluminum planchets. Eight-tenths $\mathrm{ml}$. of distilled water are added to the planchets immediately, and the contents of each planchet are carefully mixed by stirring with a clean wire. The hemolysates are dried in air overnight or in an oven at $60^{\circ} \mathrm{C}$. for about five hours and then stored in a desiccator before counting (Table I).

The red cells obtained ten minutes after the injection of the tagged erythrocytes, as well as an aliquot of the original saline suspension of tagged cells itself, are treated identically. The absorption correction is, therefore, considered uniform and may be omitted from the calculations.

For the plasma volume determination, all blood samples are spun in the centrifuge to separate the plasma. Duplicate planchets containing one $\mathrm{ml}$. of plasma each are prepared from the samples obtained just before and during the 20 minutes after the injection of the chromic chloride solution. An aliquot of the injected chromic chloride solution is diluted 1:50 with water and $1 / 2 \mathrm{ml}$. of this diluted solution is overlaid with $1 \mathrm{ml}$. of the subject's control plasma obtained at the beginning of the experiment and free of counts. The plasma and solution are well mixed in the planchets with a clean wire. Since all planchets contain $1 \mathrm{ml}$. of plasma, the absorption correction may be considered uniform and need not enter into the calculations. If the control plasma contains counts from a previous injection of isotopes, any normal plasma, free of counts, may be used, provided that the protein concentration in both plasmas is approximately the same.

All samples are dried over-night in air or in an oven at $60^{\circ} \mathrm{C}$. for about five hours. They are then stored in a desiccator until they' are counted on an end-window Geiger counter or a windowless flow type proportional counter (Table I).

The plasma sample obtained just before the injection of the chromic chloride solution serves as a control to assure that no free counts remain in the plasma from the previous injection of tagged erythrocytes.

\section{Calculations and dosage}

The circulating red cell volume of the subject is given by the formula:

Red cell volume in $\mathrm{ml}$. =

Total counts in tagged erythrocytes injected

Counts per ml. packed red cells in the subject's circulation

The plasma volume is calculated by the formula :

Plasma volume in $\mathrm{ml}$. =

98 per cent of counts injected as chromic chloride Counts per ml. of plasma at zero time

As previously given, the total radiation dose for 100 microcuries of $\mathrm{Cr}^{51}$ corresponds to 0.1 rep. In the simultaneous determination of red cell and plasma volume, the subject receives approximately 200 microcuries $\mathrm{Cr}^{51}$, or a total radiation dose of 0.2 rep. This is within the tolerance limits for human use, as is the total dose of chromium of 0.2 to $2.0 \mathrm{mg}$.

\section{RESULTS}

Combined determinations of circulating red cell mass and plasma volume have been done on ten normal individuals (Table II). The mean circulating red cell mass of these ten normal adults was $2081 \mathrm{ml}$., compared to a mean value of $2351 \mathrm{ml}$., obtained on 25 normal male students in whom the red cell mass alone was determined. The mean plasma volume in these same individuals was 2795 ml., compared to a mean value of $2894 \mathrm{ml}$., obtained on 21 normal adult males in whom the plasma volume alone was determined. Calculated on the basis of body weight, the combined method yielded a mean red cell mass of $30.3 \mathrm{ml}$. per $\mathrm{Kg}$. and a mean

TABLE II

Red cell mass and plasma volumes in ten normal adults

\begin{tabular}{|c|c|c|c|c|c|c|c|}
\hline Subject & $\begin{array}{l}\text { Total plasma } \\
\text { volume } \\
\text { ml. }\end{array}$ & $\begin{array}{l}\text { Plasma } \\
\text { volume } \\
m l . / K g .\end{array}$ & $\begin{array}{c}\text { Total red } \\
\text { cell mass } \\
\text { ml. }\end{array}$ & $\begin{array}{c}\text { Red cell } \\
\text { mass } \\
m l . / K g .\end{array}$ & $\begin{array}{l}\text { Venous } \\
\text { hct. }\end{array}$ & $\begin{array}{l}\text { Body } \\
\text { het. }\end{array}$ & $\frac{\text { Body hct. }}{\text { Ven. hct. }}$ \\
\hline $\begin{array}{l}\mathrm{Le} \\
\mathrm{Do} \\
\mathrm{Da} \\
\mathrm{Ki} \\
\mathrm{Mu} \\
\mathrm{Ga} \\
\mathrm{Ph} \\
\mathrm{Ma} \\
\mathrm{Jo} \\
\mathrm{Si}\end{array}$ & $\begin{array}{l}2180 \\
2766 \\
2803 \\
2440 \\
3130 \\
2110 \\
3770 \\
3015 \\
3005 \\
2730\end{array}$ & $\begin{array}{l}37.8 \\
40.5 \\
41.6 \\
31.6 \\
42.3 \\
34.7 \\
48.5 \\
47.7 \\
41.5 \\
45.0\end{array}$ & $\begin{array}{l}1420 \\
1909 \\
2835 \\
2550 \\
2390 \\
1834 \\
2770 \\
1680 \\
1700 \\
1720\end{array}$ & $\begin{array}{l}24.6 \\
27.9 \\
42.1 \\
33.0 \\
32.3 \\
28.8 \\
35.8 \\
26.6 \\
23.7 \\
28.4\end{array}$ & $\begin{array}{l}44.0 \\
48.8 \\
50.6 \\
48.0 \\
43.1 \\
50.5 \\
44.5 \\
49.4 \\
45.2 \\
41.2\end{array}$ & $\begin{array}{l}39.4 \\
40.8 \\
50.1 \\
51.1 \\
43.2 \\
46.5 \\
42.1 \\
35.8 \\
36.0 \\
38.1\end{array}$ & $\begin{array}{l}0.90 \\
0.84 \\
0.99 \\
1.07 \\
1.01 \\
0.92 \\
0.96 \\
0.73 \\
0.80 \\
0.93\end{array}$ \\
\hline \multirow{3}{*}{$\begin{array}{c}\text { Average } \\
\text { Standard } \\
\text { deviation } \\
\text { Standard } \\
\text { error of } \\
\text { mean }\end{array}$} & 2795 & 41.1 & 2081 & 30.3 & & & 0.91 \\
\hline & \pm 498 & \pm 5.6 & \pm 508 & \pm 5.6 & & & \pm 0.10 \\
\hline & 157 & 1.7 & 161 & 1.7 & & & 0.03 \\
\hline
\end{tabular}


plasma volume of $41.1 \mathrm{ml}$. per $\mathrm{Kg}$. The mean values, when the determinations were done separately on normal adult males, were $31.8 \mathrm{ml}$. red cells per $\mathrm{Kg}$. and $39.3 \mathrm{ml}$. plasma per $\mathrm{Kg}$. The body hematocrit was calculated by the formula: Red cell mass

Red cell mass + Plasma volume , and the ratio of the body hematocrit to the venous hematocrit was found to be $0.91 \pm 0.10$ (Table II). This is the same value as that obtained by Gibson, Peacock, Seligman, and Sack, using radioactive iron and Evans blue dye (6).

Comparison of the values obtained by different counting methods revealed agreement within 2.3 per cent, which compares well with the limits of accuracy of the method as a whole (Table III).

TABLE III

Reproducibility of a red cell mass and plasma volume determination on different counters

\begin{tabular}{lcccc}
\hline \hline & $\begin{array}{c}\text { Scintillation } \\
\text { counter } \\
m l .\end{array}$ & $\begin{array}{c}\text { Geiger } \\
\text { counter } \\
m l .\end{array}$ & $\begin{array}{c}\text { Flow } \\
\text { counter } \\
m l .\end{array}$ & $\begin{array}{c}\text { Mean } \\
\text { error } \\
\%\end{array}$ \\
\hline Plasma volume & 2730 & 2705 & 2730 & 0.5 \\
Red cell volume & 1720 & 1650 & 1660 & 2.3
\end{tabular}

What differences do occur are both positive and negative and presumably are not due to any systematic discrepancies between counting procedures.

In one individual, plasma and red cell volume determinations were performed immediately before and after transfusion of a measured quantity of whole blood (Table IV). The results agreed with the calculated values within 3 per cent, the limits of accuracy obtained in the separate determinations of red cell and plasma volume.

\section{DISCUSSION}

The feasibility of performing both red cell and plasma volume determinations by means of a single isotope, $\mathrm{Cr}^{51}$, is of considerable interest.
It has been shown by various investigators $(6,7)$ that the venous hematocrit does not represent the body hematocrit and that estimations of blood volume based on either plasma or red cell determinations and the venous hematocrit will necessarily be subject to considerable error. Various techniques have therefore been tried to determine red cell and plasma volume simultaneously (6-10).

From a practical standpoint, the $\mathrm{Cr}^{51}$ method has several advantages over these other combined methods. It requires minimum counting equipment and standardization. Further, it has now been shown that when the two procedures are done simultaneously, the technique remains simple and accurate. With the perfection of more efficient liquid sample gamma ray counters, results of red cell and plasma volume determinations can be obtained within one to two hours. This makes the method practicable for all types of clinical studies. The values obtained by counting samples in the liquid and dried state do not differ significantly.

If the subject has received a previous injection of a radioisotope, and counts remain in the plasma prior to the plasma volume determinations, the counts present in the plasma prior to the injection of chromic chloride must be corrected for in the calculation of the plasma volume.

It has been shown in the previous communication that less than 2 per cent of the intravenously injected chromic chloride tags the red cells. This was further demonstrated by determining the radioactivity of samples of red cells obtained at varying intervals before and after the injection of chromic chloride and calculating the red cell mass. The counts per $\mathrm{ml}$. of packed erythrocytes and consequently the circulating red cell mass remained unchanged throughout the experiment. Washing of the packed red cells prior to counting was not necessary, since the washed and unwashed

TABLE IV

Transfusion experiment

$H$. D. Age 66, Wt. $60 \mathrm{Kg}$.

\begin{tabular}{lcccc}
\hline & $\begin{array}{c}\text { Initial volume } \\
\text { by Crbl method } \\
\text { ml. }\end{array}$ & $\begin{array}{c}\text { Measured volume } \\
\text { transfused } \\
\text { ml. }\end{array}$ & $\begin{array}{c}\text { Calculated } \\
\text { final volume } \\
\text { ml. }\end{array}$ & $\begin{array}{c}\text { Final volume cent } \\
\text { by Crs1 method } \\
\text { ml. } \\
\%\end{array}$ \\
\hline Red cells & 2005 & 241 & 2246 & 2240 \\
Plasma & 2180 & 259 & 2439 & 0.3 \\
\hline
\end{tabular}


samples had essentially the same radioactivity. With the use of the four $\mathrm{ml}$. hematocrit tubes and one hour of centrifugation at $2700 \mathrm{rpm}$., the amount of trapped plasma did not alter the accuracy of the results.

Conversely, radioactive sodium chromate is so firmly bound to the red cells, that essentially no counts were found in the plasma ten minutes after the tagged red cells had been injected. Consequently, radioactive sodium chromate did not interfere with the plasma volume determination. It has previously been shown that the counts in the plasma are negligible for 24 hours after the injection of erythrocytes tagged with radioactive sodium chromate (2).

\section{SUM MARY}

1. Radioactive sodium chromate and chromic chloride have been employed in the simultaneous determination of both red cell mass and plasma volume in man.

2. A small aliquot of the subject's erythrocytes was tagged rapidly in vitro with radioactive sodium chromate and reinjected within a few hours.

3. A saline solution of radioactive chromic chloride was injected into the circulation, where it is rapidly bound by the plasma proteins.

4. The radioactivity of the subject's erythrocytes and plasma was determined after the injected tracer doses had mixed in the circulation.

5. Both red cell and plasma volume were calculated by the isotope dilution principle.

6. The specific affinity of chromic chloride for the plasma proteins is such that less than 2 per cent of the injected material is lost to the red cells.

7. The bond of sodium chromate to the erythrocytes is sufficiently strong so that there is no significant loss of radioactivity to the plasma.

8. The two forms of the isotope could therefore be present in the circulation simultaneously without interfering with the accuracy of either the red cell or the plasma volume determination.
9. The mean values for red cell mass and plasma volume obtained by the combined method agree favorably with those obtained when radioactive sodium chromate and chromic chloride are administered separately.

\section{ACKNOWLEDGMENTS}

Madison B. Whittier, Victor Grenda, and Jean McCormick rendered valuable technical assistance during the course of these studies.

\section{REFERENCES}

1. Gray, S. J., and Sterling, K., Determination of circulating red cell volume by radioactive chromium. Science, 1950, 112, 179.

2. Sterling, K., and Gray, S. J., Determination of the circulating red cell volume in man by radioactive chromium. J. Clin. Invest., 1950, 29, 1614.

3. Gray, S. J., and Sterling, K., The tagging of red cells and plasma proteins with radioactive chromium. J. Clin. Invest., 1950, 29, 1604.

4. Frank, H., and Gray, S. J., The determination of plasma volume in man with radioactive chromic chloride. J. Clin. Invest., 1953, 32, 000.

5. Robinson, C. V., Windowless, flow type, proportional counter for counting $C^{14}$. Science, 1950, 112, 198.

6. Gibson, J. G., 2nd., Peacock, W. C., Seligman, A. M., and Sack, T., Circulating red cell volume measured simultaneously by the radioactive iron and dye methods. J. Clin. Invest., 1946, 25, 838.

7. Hahn, P. F., Ross, J. F., Bale, W. F., Balfour, W. M., and Whipple, G. H., Red cell and plasma volumes (circulating and total) as determined by radio iron and by dye. J. Exper. Med., 1942, 75, 221.

8. Storey, R. H., Wish, L., and Furth, J., Changes in cell and plasma volumes produced by total body $\mathrm{X}$ radiation. Proc. Soc. Exper. Biol. \& Med., 1950, 74, 242.

9. Berson, S. A., and Yalow, R. S., The use of $\mathrm{K}^{22}$ or $\mathrm{P}^{\mathrm{s}}$ labeled erythrocytes and $I^{121}$ tagged human serum albumin in simultaneous blood volume determinations. J. Clin. Invest., 1952, 31, 572.

10. Scott, H. W., Jr., Elliott, S. R., II, and Clay, R. C., Blood volume in congenital cyanotic heart disease: Simultaneous measurements with Evans blue and radioactive phosphorus. Bull. Johns Hopkins Hosp., 1951, 89, 121. 